\title{
Assessment of Shippers and Ship Owners Ship and Charter Type Choice in the Wet and Dry Bulk Ship Brokering Market: Knowledge Guide for African Indigenous Ship Brokers
}

\author{
Nwokedi, Theophilus $\mathrm{C}^{1 *}$, Moses Ntor-Ue Eba ${ }^{2}$, Okonko Ifiok ${ }^{1}$ and Ndubuisi Leonard ${ }^{1}$ \\ ${ }^{1}$ Federal University of Technology, Department of Maritime Management Technology, Owerri \\ Nigeria; Email: nwokeditc@gmail.com,ifiokonko@gmail.com,ndubuisileonard@yahoo.com \\ ${ }^{2}$ Ken Sari Wiwa Polytechnic, Department of Civil Engineering, Bori, Rivers State Nigeria; Email: \\ mosaic4love@gmail.com
}

*Corresponding Author: Nwokedi, Theophilus C

Abstract: The study assessed shippers and ship owners' ship and charter party type choices in the wet and dry bulk ship broking and chartering market as guide for performance improvement for African and Nigerian ship brokers. It aims to determine if significant differences exists between shippers ship type choices among Very Large Crude Carriers (VLCC), Handymax, Supramax and capsize vessels in the wet and dry bulk market as well shippers and ship owners charter party type choice between voyage charter and time charter for the various ship types. The study adopted a survey method in which the Baltic International Maritime Council (BIMCO) was surveyed and 5 year data on ship types and charter party type choices of shippers and ship owners was obtained. The statistical tools of Analysis of Variance (ANOVA) and independent sample t-test were used to compare the ship type choices and charter party type choices of shippers and ship owners. The result indicates that shippers' in the wet and dry bulk cargo market show greater preference for Supramax vessel type. The aggregate number of vessels chartered over the period covered in the study is 41,684 vessels out of which 22,593 representing about 54.2\% are Supramax. This was seconded by VLCC which recorded 8,829 or $21.2 \%$ charters. Capsize and Handymax vessel types had 6211 and 4069 charters respectively which represent $14.9 \%$ and $9.77 \%$ each. Shippers and ship owners also show greater preference for voyage charter party type than time charter party for all types of vessels. It was recommended that ship brokers should place greater priority on trading in Supramax ship types and voyage charter party type as the demand trend for this ship type is likely to remain higher over time; followed by VLCC; while more shippers and ship owners are likely continue to show preference for voyage charter than time charter.

Keywords: Ship, charter-type, choice, indigenous-shipbrokers 


\section{Introduction}

Shipbrokers are specialist agents and intermediary negotiators that represent ship-owners and/or charterers in negotiating conditions of ship purchase and / or charter and fixing of merchant and service vessels to contracts of carriage and/ service by sea. While the sales and purchase broker offer brokerage services mostly in the new building market and functions as an intermediary agent between the buyer and the shipyard, the chartering broker functions in the ship chartering market and helps to link and fix idle vessels to competitive sea carriage contracts. In order words, ship brokering and chartering is an agency practice, where chartering brokers represent the interest of principals ( ship-owners and charterers) in negotiating the conditions and affecting the charter-in of a named vessel by a shipper(charterer) and the charter-out of the same vessel by the ship-owners( Zhiming, 2012). Ship chartering may thus be viewed as a two way process of chartering in and out of ships; facilitated by the ship broker (chartering broker).

The major difference between new building broker and chartering broker is that while the new building brokering process may be regulated by or influenced by the sale of goods contract; the chartering market is entirely dependent on the agency contract and negotiation capacity of principals and their agents influenced by forces of demand and supply. The latter is not influenced by the sale of goods contract since the owners and charters in the chartering market has neither intention whatsoever for outright sale nor outright purchase of the vessel involved. In recent time however, demand for outright purchase and ownership of vessels by States and business organizations has equally declined and continues to decline due to majorly poor or lack of access to ship acquisition credits and fund, poor professional ship management know-how and the desire to specialize solely in a particular line of trade rather than ownership and management of ships which in itself is a very complex exercise requiring professional knowledge (Jie, 2001).

The present trend favour ship chartering as need arises, thus business organizations now resort to charter in ships from professional ship owning companies (owners) as need arises. Thus ship brokering and chartering practice has over the years developed as a professional business, such that the shippers (charterers) and the ship-owners are distinct individual's specializations in different business lines (Johnson et al. 2015). Demand for the charter-in of ship from the owners therefore is derived from the need of the shipper to transport goods by sea. Brokers thus step in-between the ship-owners and shippers to offer agency services that secures a ship for the seaborne cargo and fixes the out of contract ship to a sea carriage contracts.

However, the participation of indigenous people in the ship brokering trade in Africa and Nigeria still remain rudimentarily shrouded in poor knowledge of the trade. As a result, about $60 \%$ of all vessels charter into African ports in the wet and dry bulk cargo trade was fixed by foreign 
ship brokers. The expectation in African is that African countries such as Nigeria which generate much volume of wet and dry bulk seaborne export and import should maximally benefit from all aspects related to the sea trade including ship broking and agency services and other allied maritime operations and services incidental to sea trade. The vessels conveying Nigerian export and import cargoes are not built in local shipyards nor are local brokers significantly involved in the fixing of these vessels into contracts involving Nigerian locally generated wet and dry bulk cargo exports and foreign originating imports.

To revive the trade in Nigeria require the efforts of Government, knowledge, information and training of ship brokers on the trends in ship chartering and broking market with regards ship and charter party type choices of shippers and ship owners. This study is therefore carried out to compare the ship and charter party type choices of shippers and ship owners in the wet and dry bulk market for informed entrance and participation of African indigenous ship brokers in the market. The vessel and charter party types prevalent in the market over time are as summarized below:

\begin{tabular}{|l|l|}
\hline Vessel Type/Name & Size Characteristics \\
\hline Handysize Vessels & $\begin{array}{l}\text { 40,000DWT to 60,000DWT, 150m and 200m (492-656 } \\
\text { ft) }\end{array}$ \\
\hline Supramax Vessels & \begin{tabular}{l}
$50,000 \mathrm{DWT}$ \\
\hline Very Large Crude Carriers (VLCC)
\end{tabular} \\
$\begin{array}{l}\text { 180,000 dead DWT to 320,000DWT, 470meters and } \\
\text { draught of 20meters. }\end{array}$ \\
\hline Capesize Vessels & 100,000DWT to 150,000DWT \\
\hline
\end{tabular}

Source: (Hellenic shipping news, 2018).

Zhiming (2012) supported by Timur et al.,(2012; (Evangelos et al., 19992; Brinkmann, 2008); note that vessels can be engaged in charter parties in various forms depending on charterers and owners requirements and length and / or period of time that the charter party is expected to last. The principal charter party types for engagement and hire of vessels are Voyage charter and Time charter. While Freight is paid by charterer in Lump-sum in voyage charter, Charterer in a time charter party the charterer pays hire per specified period of time, i.e. on a daily or monthly basis.

\subsection{Aim and Objectives of the Study}

The aim of this research is to assess the charter type choices for shippers and ship owners in the wet and dry bulk cargo market with regards to the types of vessel choices and charter party (time and voyage charter) type choices in order to provide empirical evidence to guide African indigenous ship brokers on trends of events in the wet and dry bulk cargo market. The specific objectives of the study include the following: 
a) To compare shippers' choices of VLCC, Handymax, Capsize and Supramax vessel types in the wet and dry bulk market within the period 2011 to 2015.

b) To determine the difference between the shippers' and ship owner's charter party type choice for VLCC vessels fixed into time charter and voyage charter fixtures over the period covered in the study.

c) To determine the existence of a significant difference in shippers the charter party type choice of Handymax vessels employed in time charter and voyage charter in the wet and dry bulk market.

d) To measure the significance of differences in shippers and ship owners charter party type choice of capsize vessels in the wet and dry bulk cargo market.

e) To compare charter party type choice for Supramax vessels fixed in time and voyage charter party types over the period covered in the study.

\subsection{Research Questions}

a) Is there any significant difference in shippers' choices of VLCC's, Handymax, Capsize and Supramax vessel types in the wet and dry bulk market within the period covered in the study?

b) What is the difference between the shippers' and ship owner's charter party type choice for VLCC vessels fixed into time charter and voyage charter fixtures over the period covered in the study?

c) Is there any significant difference charter party type choice of Handymax vessels employed in time charter and voyage charter in the wet and dry bulk market?

d) Does significant difference exist in shippers and ship owners charter party type choice of capsize vessels in the wet and dry bulk cargo market?

e) What is the difference in the number of Supramax vessels fixed in time and voyage charter party types over the period covered in the study?

\section{Brief Review of Literature}

Ship Chartering according to Zhiming, (2012) is a rental agreement in which a charterer agrees to hire a ship from the ship owner; with the agreement to pay a consideration to the ship owner in form of hire money technically referred to as "freight" and which represent the reward to the ship owner for the use of his vessel. The Contracts on which ship chartering agreements are drawn are referred to charter-parties and charter-parties represent contracts for the use of the vessel for a period of time stipulated in the Charter-party. This quite different from a bill of laden contract which represent a 
contract for carriage of good s by sea by a named carriage or contract for the use of part of the ship as agreed between a named carrier and the shipper (Ashok, 2012; Paolo et al., 2014).

The Baltic Exchange is the world's only independent source of maritime market information for the trading and settlement of physical and derivative ship broking and chartering (charter party) contracts. Its international community of over 600 member ship broking firms encompasses the majority of the world shipping interests who commits to a code of business conduct overseen by the Baltic Exchange. Baltic Exchange is headquartered in London, with regional offices in Singapore, Shanghai and Athens. Baltic Exchange members are responsible for a large proportion of all dry cargo and tanker fixtures as well as the sale and purchase of merchant vessels. The exchange provides daily freight market prices and maritime shipping cost indices which are used to guide freight traders as to the current level of various global shipping markets as well as being used to set freight futures known as forwards freight Agreements or FFAs and spot charter prices (Goulielmos and Psifia, 2007).

Most tankers and dry bulk vessels are traded under spot or time charter contracts. The spot freight rate is the freight rate a vessel receives on a United States Dollar (USD) per tonne of cargo basis for a single voyage. For tankers, spot rates are reported in World scale.

The reference rate, also known as the flat rate, is reported as World scale 100 (WS100), and reflects the costs in USD of transporting a tonne of cargo for a standard vessel on a route-specific round voyage. The fixed rate for hire is set per day relative the prevailing economic factors of ship demand and supply cum availability of cargo which equally determines ship demand (Lansdale \& Verreet, 2013).

Hellenic shipping news (2018) reports that the BDI peaked in 2008 hitting 11,793 points and in November 2015 hit an all-time low of 498 points. This was traceable to the Global Economic Recession which limited the volume and tonnage of global seaborne trade thus leading to supply of vessels by ship-owners curious about engaging their vessels to contract so as to be able to meet up with loan servicing obligations. As a result, the daily earnings rate of Supramax and Handymax vessels for example dropped to between $\$ 7,000$ and $\$ 8,000$ per day in 2015 from peak of $\$ 70,000$ per day in November 2007 for one-year time charters and raised the levels of both second-hand vessel sales and vessels sold for scrap. This implies that fewer or no new-build orders are expected as oversupply continues (Hellenic shipping news, 2018). It was forecasted by Drewry (2016) that future charter rates will improve to around $\$ 16,000+$ per day in year 2017 as the oversupply is expected to fall away. For Time Charter rates (TCE), the total voyage cost for the particular voyage is deducted from the total freight payment and then finding the net freight payment. The net freight payment is then divided by number of days the vessel is determined to be fixed in time charter contract, resulting 
in the TCE in USD/day. At present, 2018 market condition suggests slight improvement in both time and spot charter rates (Helenic shipping news, 2018). However over supply situations still persist with time charter rates for wet bulk trade slightly rising above time charter rates for dry bulk market within the Atlantic (ATL) and Pacific (PAC) sea routes. The estimates are as presented below in the table below:

Table 1 Dry Bulk Time Charter Rate Estimates as at April, 2018 (USD/dpr). Source: Hellenic shipping news (2018)

\begin{tabular}{l|l|l|l|l|l|l}
\hline \multirow{2}{*}{ Size/Period } & \multicolumn{2}{l}{ 6months } & \multicolumn{2}{l}{ 1Year } & \multicolumn{2}{l}{ 2Years } \\
\cline { 2 - 8 } & ATL & PAC & ATL & PAC & ATL & PAC \\
\hline Handy (32,000dwt) & 12,000 & 10,250 & 9,500 & 9,250 & 9000 & 9000 \\
\hline Supra (52,000dwt) & 16,000 & 13,000 & 14,500 & 12,500 & 12,500 & 12,500 \\
\hline Ultra (62,000dwt) & 16,500 & 13,500 & 16,000 & 13,000 & 13,000 & 12,750 \\
\hline Panamax (72,000dwt -82, 000dwt) & 15,500 & 15,000 & 14,750 & 15,000 & 13,500 & 13,500 \\
\hline Capsize (170,000dwt) & 15,500 & 15,500 & 17,750 & 17,750 & 18,000 & 18,000 \\
\hline
\end{tabular}

The shows the time rate estimates in April 2018 indicating higher time charter rates for higher capacity vessels and difference in charter between the pacific and Atlantic sea regions for differing charter periods. Only the capsize charter rates remain the same for both sea regions for each charter period.

Table 2 Liquid Bulk/Wet (Tanker) time Charter Rate Estimates As at April, 2018 (USD/dpr). Source: Hellenic shipping news (2018)

\begin{tabular}{l|l|l|l|l}
\hline Size/Period & 1 year & 2 Years & 3 Years & 5Years \\
\hline Handy $(40,000 \mathrm{dwt})$ & 12,750 & 13,250 & 13,800 & 14,000 \\
\hline AFRA $(115,000 \mathrm{dwt})$ & 14,500 & 15,250 & 17,000 & 18,000 \\
\hline SUEZ $(120,000 \mathrm{dwt}-200,000 \mathrm{dwt})$ & 16,350 & 17,250 & 20,000 & 23,000 \\
\hline VLCC $(250,000 \mathrm{dwt})$ & 21,750 & 26,500 & 28,500 & 32,500 \\
\hline
\end{tabular}

As expected the time charter rate of the tankers per day increases depending on the capacity of the tankers, an indication that notwithstanding the demand and supply, ship capacity of tonnage equally affects and /or influences time charter rates. This why the VLCC show highest charter rates of 21, 750 USD, 26,500USD, 28,500USD and 32,500USD per day respectively for the 1year, 2years, 3years and 5years charter period as against those of smaller capacity vessels as HANDYSIZE and SEUZMAX which showed lesser time charter rates. The table2 above shows time charter rates for both crude and refined oil tankers, Liquefied Natural Gas carriers (LNG) and chemical tankers (chemical carriers). 


\section{Methodology}

The study adopted an investigative approach to compare the charter type choice of wet and dry bulk shippers and ship owners. It obtained time series secondary data covering a period of 5years on the size/numbers of time charter and voyage charter type choice by shippers and ship owners covering various ship types such as HANDYMAX, VLCC, SUPRAMAX and CAPSIZE. Data was obtained from the Baltic International Maritime Council (BIMCO) covering the period from 2011 to 2015. The statistical tools of Analysis of Variance (ANOVA) and Independent sample T-test was used to compare time and voyage charter type choice for each class of vessel as well as the vessel type choice of shippers while students.

\section{Result and Discussion}

Table 3 Comparing shippers ship type choice using ANOVA method. Source: authors calculation based on data collected

\begin{tabular}{|c|c|c|c|c|c|c|}
\hline \multicolumn{5}{|c|}{ ANOVA: Two-Factor Without Replication } & & \\
\hline SUMMARY & Count & Sum & Average & Variance & & \\
\hline 2011 & 4 & 7122 & 1780.5 & 2718186 & & \\
\hline 2012 & 4 & 7689 & 1922.25 & 3584032 & & \\
\hline 2013 & 4 & 8012 & 2003 & 3730950 & & \\
\hline 2014 & 4 & 9016 & 2254 & 2312601 & & \\
\hline 2015 & 4 & 9809 & 2452.25 & 2081011 & & \\
\hline Handymax & 5 & 4069 & 813.8 & 77457.7 & & \\
\hline VLCC & 5 & 8829 & 1765.8 & 406.7 & & \\
\hline Supramax & 5 & 22539 & 4507.8 & 65450.7 & & \\
\hline Capesize & 5 & 6211 & 1242.2 & 593497.7 & & \\
\hline \multicolumn{7}{|l|}{ ANOVA } \\
\hline $\begin{array}{l}\text { Source } \\
\text { Variation }\end{array}$ & $S S$ & $d f$ & $M S$ & $F$ & $P$-value & $F$ crit \\
\hline Rows & 1157326 & 4 & 289331.6 & 1.939734 & 0.168398 & 3.259167 \\
\hline Columns & 41490414 & 3 & 13830138 & 92.7199 & $1.44 \mathrm{E}-08$ & 3.490295 \\
\hline Error & 1789925 & 12 & 149160.4 & & & \\
\hline Total & 44437665 & 19 & & & & \\
\hline
\end{tabular}

The results provides evidence that the averages of Handymax, VLCC, Supramax and Capsize vessel types chartered in the wet and dry bulk over the five years period covered in the study are $813.8,1765.8,4507.8$ and 1242.2 respectively. The result equally indicate that the annual average of all vessel types chartered in each year covered in the study are 1780.5, 1922.25, 2003, 2254 and 2452.2 vessels in 2011, 2012, 2013, 2014 and 2015 respectively. This shows an increasing trend in demand for vessel charter in the wet and dry bulk market showing shippers higher preference for Supramax vessels which recorded highest demand over the period. The demand and preference for 
VLCC is second followed by shippers demand for Capesize vessels. Handymax recorded the least demand and preference by shippers. The implication of this to brokers and the chartering market is that priority should be on ensuring greater supply of Supramax vessels to meet increasing market demand. New building order for Supramax vessel is equally expected increase in the future to be able to meet increasing demand; without this, a shortage is supply may push charter rates higher away from current freight levels and equilibrium point. A comparison of the differences in charter choice of various ship types over the period covered in the study indicates an F-ratio of 92.7, Pvalue of $1.44 \mathrm{E}-08$ and F-critical of 3.49. Thus we conclude that a significant difference exists in shipper's choice of ship types in the wet and dry bulk chartering market.

Table 4 Comparing the Charter Party Type choice of VLCC's. Source: authors presentation based on output

\begin{tabular}{ll|l|l|l|lc}
\hline \multicolumn{2}{l|}{ Paired Samples Statistics } & N & $\begin{array}{l}\text { Std. } \\
\text { Deviation }\end{array}$ & $\begin{array}{l}\text { Std. } \\
\text { Mean }\end{array}$ & Error \\
\hline VLCC & Mean & 5 & 11.649 & 5.210 & \\
\hline \multirow{2}{*}{ Pair 1 Voyage } & 1732.80 & 53.00 & 5 & 14.353 & 6.419 & \\
\hline
\end{tabular}

\begin{tabular}{|c|c|c|c|c|c|c|c|c|c|}
\hline \multicolumn{10}{|c|}{ Paired Samples Test } \\
\hline & & \multicolumn{5}{|c|}{ Paired Differences } & \multirow{3}{*}{ t } & \multirow[t]{3}{*}{$\mathrm{df}$} & \multirow{3}{*}{$\begin{array}{l}\text { Sig. (2- } \\
\text { tailed) }\end{array}$} \\
\hline & & \multirow[t]{2}{*}{ Mean } & \multirow[t]{2}{*}{$\begin{array}{l}\text { Std. } \\
\text { Deviation }\end{array}$} & \multirow{2}{*}{$\begin{array}{l}\text { Std. } \\
\text { Error } \\
\text { Mean }\end{array}$} & \multicolumn{2}{|c|}{$\begin{array}{l}95 \% \text { Confidence Interval } \\
\text { of the Difference }\end{array}$} & & & \\
\hline & & & & & Lower & Upper & & & \\
\hline Pair 1 & $\begin{array}{l}\text { Voyage } \\
\text { Time }\end{array}$ & 1699.800 & 16.634 & 7.439 & 1679.146 & 1720.454 & 228.496 & 4 & .000 \\
\hline
\end{tabular}

The analysis sought to determine the existence of significant difference in shippers and ship owners charter party type choice of VLCC vessels. The results indicates that within the 5 years period covered in the study, a mean number of 1732.80 and 33.0 vessels were employed in voyage and time charter party types respectively. This indicates a mean difference 1699.80 vessels in favour of voyage charter party type with a standard deviation of 16.63 . The implication is that shippers and ship owners in the wet bulk cargo market are more favourably disposed to choosing fixing VLCC vessels more frequently in voyage charters than in time charter. The t-test shows a tstatistic of 228.49, t-table of 2.13 and P-value of 0.00 at 4 degrees of freedom. Thus we conclude that there is a significant difference in shippers' charter party type choice between voyage and time charters for VLCC vessels. 
Table 5 Comparison of shippers and ship owners charter party type choices of voyage and time charter for Handymax by paired samples statistics. Source: authors

\begin{tabular}{ll|l|l|l|ll}
\hline \multicolumn{2}{l|}{ Paired Samples Statistics } & \multicolumn{3}{l}{} \\
\hline & Mean & $\mathrm{N}$ & $\begin{array}{l}\text { Std. } \\
\text { Deviation }\end{array}$ & $\begin{array}{l}\text { Std. Error } \\
\text { Mean }\end{array}$ \\
\hline \multirow{2}{*}{ Pair 1 } & Voyage & 722.20 & 5 & 288.340 & 128.949 & \\
& Time & 85.60 & 5 & 7.797 & 3.487 & \\
\hline
\end{tabular}

\begin{tabular}{|c|c|c|c|c|c|c|c|c|}
\hline \multicolumn{9}{|l|}{ Paired Samples Test } \\
\hline & \multicolumn{5}{|c|}{ Paired Differences } & \multirow{3}{*}{$t$} & \multirow[t]{3}{*}{$\mathrm{df}$} & \multirow{3}{*}{$\begin{array}{l}\text { Sig. (2- } \\
\text { tailed) }\end{array}$} \\
\hline & \multirow[t]{2}{*}{ Mean } & \multirow[t]{2}{*}{$\begin{array}{l}\text { Std. } \\
\text { Deviation }\end{array}$} & \multirow[t]{2}{*}{$\begin{array}{l}\text { Std. } \\
\text { Error } \\
\text { Mean }\end{array}$} & \multicolumn{2}{|c|}{$\begin{array}{ll}95 \% \text { Confidence } \\
\text { Interval of the } \\
\text { Difference }\end{array}$} & & & \\
\hline & & & & Lower & Upper & & & \\
\hline $\begin{array}{ll}\text { Pair } & \text { Voyage }- \text { Time } \\
1 & \end{array}$ & 636.600 & 292.321 & $\begin{array}{l}130.73 \\
0\end{array}$ & 273.636 & 999.564 & 4.87 & 4 & .008 \\
\hline
\end{tabular}

The results indicates that within the 5 years period covered in the study, a mean number of 722.20 and 85.0 vessels were employed in voyage and time charter party types respectively by shippers. This indicates a mean difference 636.60 vessels in favour of voyage charter party type with a standard deviation of 292.321. The implication is that shippers and ship owners in the wet and dry bulk cargo market choose to charter in and out more Handymax in voyage charter party type than in time charter. The t-test shows a t-statistic of 4.87, t-table of 2.13 and P-value of 0.008 at 4 degrees of freedom. Thus we conclude that there is a significant difference in shippers' charter party type choice between voyage and time charter party types for Handymax.

Table 6 Comparison of shippers and ship owners charter party type choices of voyage and time charter for Capsize by paired samples statistics Source: authors calculation

\begin{tabular}{ll|l|l|l|l}
\hline Paired Samples Statistics & \multicolumn{3}{l}{} \\
\hline & Mean & $\mathrm{N}$ & $\begin{array}{l}\text { Std. } \\
\text { Deviation }\end{array}$ & $\begin{array}{l}\text { Std. Error } \\
\text { Mean }\end{array}$ \\
\hline \multirow{2}{*}{ Pair 1 } & Voyage & 1193.00 & 5 & 743.567 & 332.533 \\
& Time & 53.20 & 5 & 27.041 & 12.093 \\
\hline
\end{tabular}




\begin{tabular}{|c|c|c|c|c|c|c|c|c|c|}
\hline \multicolumn{10}{|c|}{ Paired Samples Test } \\
\hline & & \multicolumn{5}{|c|}{ Paired Differences } & \multirow[t]{3}{*}{$\mathrm{t}$} & \multirow[t]{3}{*}{$\mathrm{df}$} & \multirow{3}{*}{$\begin{array}{l}\text { Sig. (2- } \\
\text { tailed) }\end{array}$} \\
\hline & & \multirow[t]{2}{*}{ Mean } & \multirow[t]{2}{*}{$\begin{array}{l}\text { Std. } \\
\text { Deviation }\end{array}$} & \multirow[t]{2}{*}{$\begin{array}{l}\text { Std. Error } \\
\text { Mean }\end{array}$} & \multicolumn{2}{|c|}{$\begin{array}{l}95 \% \text { Confidence Interval } \\
\text { of the Difference }\end{array}$} & & & \\
\hline & & & & & Lower & Upper & & & \\
\hline $\begin{array}{l}\text { Pair } \\
1\end{array}$ & $\begin{array}{l}\text { Voyage } \\
\text { - Time }\end{array}$ & 1139.800 & 721.638 & 322.726 & 243.768 & 2035.832 & 3.532 & 4 & .024 \\
\hline
\end{tabular}

The results indicates that within the 5 years period covered in the study, a mean number of 1193.00 and 53.0 Capsize vessels were employed in voyage and time charter party types respectively by shippers. This indicates a mean difference 1139.800 capsize vessels in favour of voyage charter party type with a standard deviation of 721.638. The implication is that shippers and ship owners in the wet and dry bulk cargo market choose to charter in and out more Capsize by voyage charter party type than in time charter. The t-test shows a t-statistic of 3.532, t-table of 2.13 and $\mathrm{P}$-value of 0.028 at 4 degrees of freedom. Thus we conclude that there is significant differences in shippers' charter party type choice between voyage and time charter party types for capsize.

Table 7 Comparison of shippers and ship owners charter party type choices of voyage and time charter for Supramax by paired samples statistics Source: authors calculation.

\begin{tabular}{ll|l|l|l|l}
\hline \multicolumn{2}{l|}{ Paired Samples Statistics } & \multicolumn{3}{l}{} \\
\hline & Mean & N & $\begin{array}{l}\text { Std. } \\
\text { Deviation }\end{array}$ & $\begin{array}{l}\text { Std. Error } \\
\text { Mean }\end{array}$ \\
\hline \multirow{2}{*}{ Pair 1 } & Voyage & 4400.20 & 5 & 239.653 & 107.176 \\
& Time & 107.60 & 5 & 32.362 & 14.473 \\
\hline
\end{tabular}

\begin{tabular}{|c|c|c|c|c|c|c|c|c|c|}
\hline \multicolumn{10}{|c|}{ Paired Samples Test } \\
\hline & & \multicolumn{5}{|c|}{ Paired Differences } & \multirow{3}{*}{$\mathrm{t}$} & \multirow[t]{3}{*}{$\mathrm{df}$} & \multirow{3}{*}{$\begin{array}{l}\text { Sig. (2- } \\
\text { tailed) }\end{array}$} \\
\hline & & \multirow[t]{2}{*}{ Mean } & \multirow[t]{2}{*}{$\begin{array}{l}\text { Std. } \\
\text { Deviation }\end{array}$} & \multirow{2}{*}{$\begin{array}{l}\text { Std. } \\
\text { Error } \\
\text { Mean }\end{array}$} & \multicolumn{2}{|c|}{$\begin{array}{l}95 \% \text { Confidence Interval } \\
\text { of the Difference }\end{array}$} & & & \\
\hline & & & & & Lower & Upper & & & \\
\hline $\begin{array}{l}\text { Pair } \\
1\end{array}$ & $\begin{array}{l}\text { Voyage } \\
\text { - Time }\end{array}$ & 4292.600 & 226.961 & 101.500 & 4010.791 & 4574.409 & 42.292 & 4 & .000 \\
\hline
\end{tabular}

The results indicates that within the 5 years period covered in the study, a mean number of 4400.20 and 107.0 Handysize vessels were employed in voyage and time charter party types respectively by shippers. This indicates a mean difference 4292.600 Handysize vessels in favour of voyage charter party type with a standard deviation of 226.961. The implication is that shippers and ship owners in the wet and dry bulk cargo market choose to fix more Handysizes in voyage charter 
party type than in time charter. The t-test shows a t-statistic of 42.292, t-table of 2.13 and P-value of 0.00 at 4 degrees of freedom. Thus we conclude that there is significant differences in shippers' charter party type choices between voyage and time charter party types for Handysize.

\section{Answer to Research Questions}

a) The findings of the study indicate that there is a significant difference is shippers' choices of VLCC, Handymax, Capsize and Supramax vessels types with Supramax vessel type having the highest demand/choice of 4507.8 per annum. Handymax vessel type had the least average demand per annum of 813.8. VLCC and Capsize had average annual demands of 1765.8 and 1242.2 respectively. The implication is that shipper's preferences among vessel types significantly differ and is greatest for Supramax vessels. Ship owners are therefore likely to increase investment in the supply of Supramax in order to meet up with demand. Ship brokers too should develop connections that can give them easy accessibility to owners of Supramax vessels in order to be able to meet charter orders as they arise.

b) The findings indicate that a significant difference exist between the charter party type choices for VLCC vessels. It shows averages of 1732.80 and 33.00 VLCC vessels engaged in voyage and time charter party types respectively per annum. The mean difference is 1699.80 in favour of voyage charter party; an indication of the greater preferences of ship owners and shippers for employment of VLC vessels in voyage charter than in time charter. It implies that with regards to the charter of VLCC's, ship brokers should favourably dispose themselves greater to the principles of time charter party negotiations.

c) Yes, a significant difference exists between shippers and ship owners' charter party type choice of Handymax vessels in the wet and dry bulk cargo market. The average annual number of capsize vessels engaged in voyage and time charter party types are 722.20 and 85.60 respectively. The difference of mean is 636.600 in favour of time charter. The t-value of 4.87 against a t-table of 2.13 indicates that a significant difference exists. With Handymax, shippers and ship owners prefer voyage charter party time.

d) Yes, a significant difference exists. More Capsize vessels were employed in voyage charter that in time charter revealing further shippers and ship owners' greater preference to fix capsize vessels in voyage charter than in time charter. With a difference of mean of 1139.0 vessels in favour of voyage charter party type, a t-statistic of 3.532, t-table of 2.13 and P-value of 0.028 at 4 degrees of freedom; we conclude that there is significant differences in shippers' and ship 
owners' charter party type choice between voyage and time charter party types for capsize vessels.

e) The paired sample statistics indicates that the difference of mean between charter party type choices of voyage and time charter for Supramax vessels is 4292.0; indicating greater preference for voyage charter party type.

\section{Conclusion}

Based on the findings of the study, the study concludes that shippers' in the wet and dry bulk cargo market show greater preference for Supramax vessel type. The aggregate vessel of vessels chartered over the period covered in the study is 41,684 vessels out of which 22,593 representing about $54.2 \%$ are Supramax vessel. This is seconded by VLCC which recorded 8,829 or $21.2 \%$ charters. Capsize and Handymax vessel types had 6211 and 4069 charters respectively which represent $14.9 \%$ and $9.77 \%$ each. Shippers and ship owners also show greater preference for voyage charter party type than time charter party for all types of vessels.

\section{Recommendation}

Since the interest of the ship broker is to earn and maximize economic from the service/trade by fulfilling the interest of the principal ship owner and shipper by linking and fixing the cargo to ship and ship to trade. The broker can only maximize his economic interest by fixing greater part of the ship owners and shippers demand. This can only be possible the brokers' service supply goes in the same direction with the shippers and ship owners demand. In line with the aforementioned, it is recommended that African and Nigerian ship brokers should place greater priority on trading in Supramax ship types and mastering the principles and rules of voyage charter party type such that their supply of services for both Supramax and voyage charter party should be greater as the demand trend for this ship type is likely to remain higher over time; followed by VLCC; while more shippers and ship owners are likely continue to show preference for voyage charter than time charter.

\section{References}

[1] Ashok Mulloth (Retrieved on 23/06/207) Shipbroking and Chartering Essentials- Offshore. Available at: http//www.sp.edu.sg.

[2] Brinkmann, H. (2008). Shipbroker- Is the future fixed? A Final Year Project in the Department of Shipping, University of Greenwich. Available at: www.brinkmann.co.uk/.../shipbroker. Retrieved on 23/11/17 . 
[3] Evangelos, F., Harilaos, N. \& Nikolaos M. (1992). Quantitative Method in shipping: A Survey of Current Use and Future Trends. Available at: www.aueb.gr/user/magirou/SHIP92. (Retrieved on 31/5/2016).

[4] Furset, O. \& Hordnes, E. (2013). The VLCC Tanker Market: The Present, Past and Future: An M.Sc.Thesis at Norwegian School of Economics and Business Administration. Bergen Norway. Available at: https://brage.bibsys.no//Furset_org. (Retreived on the 4/7/2016).

[5] Hellenic Shipping News. (2018). Daily Ship Chartering and Ship building News. Available at: www.hellenic shippingnews/.

[6] Iheanyi, N. (2016). An Assessment of Ship Brokering Management Practices in The Shipping Industry. A First Degree Project in the Department of Maritime Management Technology, Federal University of Technology, Owerri.

[7] Johnson, H. \& Linda, S. (2015). Increased energy efficiency in short sea shipping through decreased time in port. Transportation Research Part A, 71, 167-178.

[8] Jie, L. (2001). Chartering policies in Dry Bulk Market: Ph.D Dissertation at The World Maritime University, Malmo. Paper 202.

[9] Krishna, P. (2009). Changing Role of Shipbrokers: A Study of the Impact of Modern Communication in Practical Shipbroking. Available at: www.he_alert.org/he00915.pdf. (Retrieved on the20/3/2016).

[10] Paolo, A., Tristan, S. \& Nishat, R. (2014). Energy efficiency and time charter rates: Energy efficiency Savings recovered by ship owners in the Panamax market. Transportation Research Part A, 66, 173-184.

[11] Plomaritou, E. (2014). A review of Ship-owner's and charterers' obligations in various types of charter: Journal of Shipping and Ocean Engineering, 4, 307-321.

[12] Timur, O. \& Ismail, B. (2012). A Study on The Charter Type Choice of Turkish General Cargo and Dry bulk Ship owners. The Asian Journal of Shipping and Logistics, 28 (2), 203226.

[13] Zhiming, H. (2012). Chartering Shipbroker and Related Issues in China. An M.Sc Thesis in Department of Maritime Law, Lund University. 